\title{
Iššūkiai valstybės tarnybai naujojo viešojo valdymo kontekste
}

\author{
Alvydas Raipa \\ Mykolo Romerio universitetas \\ Ateities g. 20, 08303 Vilnius \\ doi:10.13165/VPA-14-13-4-01
}

\begin{abstract}
Anotacija. Viena iš socialiniu sistemu transformacijos rūš̌iu yra viešojo valdymo sistemu kaita. Valstybès tarnybos pokyčius suponuojantys iššūkiai yra globalaus pobüdžio reiškiniai, reikalaujantys viešojo valdymo modernizavimo, valstybès tarnybos reformu, nauju inovaciniu valdymo formu kürimo ir igyvendinimo. Šiandien, valstybès tarnybos, kaip viešojo valdymo posistemès, funkcionaluma lemia veiklos modernizavimo procesu kokybiniai parametrai, interesu grupiu integralumo lygmuo, inovatyvios ideologijos pletra ir inovacijoms palankiu salygu formavimas, t. y. platus spektras objektyviu sąlygu ir subjektyviu faktoriu, ju komponentu rinkinys. Iššükiai valstybès tarnybai tiesiogiai siejami su integruoto valdymo konstrukcijomis, kompleksinio valdymo dimensijomis. Tai aktualizuoja valstybès tarnybos organizacinès funkcinès pertvarkos, veiklos reformavimo bütinuma, modernizavimo krypčiu ir tendenciju strateginiu prioritetu išskyrima tiek globalioje, tiek lokalioje (Lietuvos) aplinkoje. Straipsnyje dèmesys sutelkiamas i universalius valstybès tarnybos kaitos procesus bei atskiru Lietuvos valstybes tarnybos pertvarkos fragmentu identifikavima ir eksplanavima.
\end{abstract}

Raktažodžiai: iššukiai, naujasis viešasis valdymas, pokyčiai, inovacijos, veiklos vertinimas, kompetencija, tarpsektorine integracija.

Keywords: challenges, new public governance, changes, innovations, performance evaluation, competency, inter sector integration.

\section{Ivadas}

Šiame straipsnyje autoriai nesiekia aptarti visų modernaus valdymo ir jo sudètinès dalies - valstybès tarnybos funkcionavimo procesų. Suvokiant viešąji valdymą kaip struktūrinę funkcinę dimensiją, bandoma pagrịsti šios dimensijos, kaip 
valdymo teorijos bei valstybės valdymo praktikos, visumą bei specifikuoti valstybès tarnybai, valstybès tarnautojams iškilusius iššūkius, remiantis viešojo valdymo evoliucionavimo pasauline praktika bei teorinių požiūrių kaita. Šiandien tai neįmanoma atlikti be globalių pokyčiu analitinio konteksto, globalių procesų įtakos viešojo valdymo sistemų, visų rūšiu viešojo valdymo struktūrų, valstybės tarnybos veiklos modernizavimui.

Analizuojant viešojo valdymo evoliuciją XXI a. pradžioje, viena iš svarbiausių valdymo kaitos proceso dedamųjų tampa valstybės tarnybos modernizavimo būtinumas, suprantamas kaip viešojo valdymo pokyčiai valdymo strategijų, programų ir projektų, sprendimų rengimo ir igyvendinimo, demokratinių viešojo valdymo procesų įtvirtinimo srityse. Todèl valstybės tarnybos kaip sistemos efektyvus funkcionalumas, viešojo valdymo institucijų, valstybès tarnautojų veikla, tiesiogiai priklauso nuo valstybės tarnautojų kompetencijų ir gebejjimų ugdymo kokybiniais parametrais, t. y. itin svarbiais valdymo modernizavimo reformų komponentais tampa ne atskiri instituciniai ar asmeniniai gebejjimai, o valstybės tarnautojų, kaip socialinės grupès, pasirengimas savo veikloje įdiegti platų spektrą inovacinių modernizavimo metodikos elementų, t. y. ịvaldyti viešojo valdymo modernizavimo metodologinị instrumentarijų. Tai reikalauja iš viešojo valdymo teoretikų, valstybės tarnautojų naujų, kartais gana radikalių požiūrių ị nusistovejjusias teorines ekonomines, politines, socialines doktrinas, egzistuojančius viešojo valdymo praktikos modelius, metodus ir procedūras, formuojant naujas valdymo reformų, procesų charakteristikas, būtinas reinventorizuojant valstybès tarnybos inkrementinị reformavimą ir identifikuojant bei įtvirtinant inovacines modernizavimo formas viešojo valdymo globalioje socialinèje, politineje, ekonomineje erdveje. Todèl straipsnio autorių tikslas - išskirti ir pagrịsti bendriausius iššūkius valstybès tarnybai kaip universaliai viešojo valdymo struktūrinei dimensijai, fragmentuotai atspindint kai kuriuos Lietuvos valstybès tarnybos kaitos procesus XXI a. pradžioje.

\section{Valstybės tarnybos funkcionalumą lemiantys faktoriai}

Bandant analizuoti XXI amžiuje besiformuojančias globalios visuomenès kompleksinès plètotès kryptis ir tendencijas, reikalinga ne tik gebèti išskirti viešojo valdymo evoliucionavimo trajektorijas, bet ir siekti tiksliai nustatyti ir ịvardinti viešojo valdymo (kur svarbiausiu komponentu išlieka valstybės tarnyba kaip visuminis organizacijų funkcijų, vertybių, elgsenos komponentų ir procesų darinys), funkcionalumo faktorius. Todèl detalizuojant ir strateguojant valstybès tarnybos, kaip struktūrų ir tarnautojų visumos dekompoziciją, itin svarbiu faktoriumi tampa analitikų ir praktiku gebejjimai identifikuojant esminius naujojo, t. y. XXI a. viešojo valdymo indikatorius, kurie gali padèti formuoti tiek visos viešojo valdymo sistemos, tiek valstybės tarnybos, kaip jos posistemès, tolesnių kaitos reformų, modernizavimo procesų turinį, kadangi dar $2003 \mathrm{~m}$. kai kurie teoretikai jau išskyré naujosios viešosios tarnybos terminą, kurị identifikavo kaip naujojo viešojo valdymo esminị komponentą [2]. 
Teoretikai ịvairiai interpretuoja naujojo viešojo valdymo kaip besiformuojančios naujos valdymo paradigmos struktūrą. Tačiau, šiandien jau galima išskirti esmines naujojo viešojo valdymo dedamąsias ir pateikti jas indikuojančias (dažnai diskutuotinas) charakteristikas. Tai nèra galima atlikti remiantis vien tik mechanistinių principų taikymu vertinant valdymo procesų evoliuciją kaip objektyvesnį reiškinị. Valdymo sistemų transformacijų ir reformų procese itin svarbus visuomenės stratifikacijos elementų - interesų grupių, politinių darinių, verslo sektoriaus ir nevyriausybinių organizacijų, valstybės, viešojo valdymo institucijų lyderių, politikų ir administratorių ịnašas, pastangos ir gebejjimai, tiesiogiai veikiantys modernizavimo procesų turinị, reformų inovatyvų pobūdị, pilietinès visuomenės konstrukcijų vietą ir vaidmeni XXI a. valdyme [19, p. 255-256].

Valstybės tarnybos veiklos modernizavimas XXI amžiuje suprantamas kaip procesas, apimantis tikslus ir užduotis tobulinant valstybės tarnautojų profesionalumą atliekant jiems paskirtas funkcijas, struktūrinius pertvarkymus, būtinus sklandžiam valstybės institucijų funkcionavimui. Valstybės tarnybos modernizavimas naujojo viešojo valdymo kontekste yra tiesiogiai siejamas su viešojo intereso visose visuomeninio gyvenimo sferose gynimu, pilietinès visuomenès institutų formavimu ir piliečių dalyvavimo plètra valdyme, valdymo demokratizavimu centralizuojant ir decentralizuojant valdymo procesą, institucijas bei funkcijas. Toks platus požiūris ị valstybès tarnybos funkcionalumą kaip tam tikrą sistemą su daugybe komponentų, t. y. subsisteminių darinių, leidžia geriau suprasti platų spektrą problemų, aptarti valstybės tarnybos modernizavimo dekompoziciją šiuolaikiniame viešojo valdymo evoliucijos etape. Straipsnyje keliami uždaviniai siejami su XXI a. pradžios pokyčiu suponuotomis globaliomis viešojo valdymo kaitos, reformų būtinumo, jų esminių krypčių, indikatorių ir tendencijų indentifikavimu valstybès tarnyboje, kai karjeros modelis palaipsniui buvo liberalizuojamas siekiant ịtvirtinti valstybės tarnyboje postų modelị, sudariusị tam tikras galimybes sutelkti pastangas perskirstyti ir racionalizuoti daugelị valstybės tarnybos funkcijų bei visų rūšiu išteklius (visų pirma, žmogiškuosius), pereiti prie naujų valdymo modernizavimo krypčių, stiprinant valstybės tarnybos institucijų ir organizacijų vadovų atsakomybę ir tobulinant jų veiklos kontrolès bei vertinimo procedūras, plètojant iš naujosios viešosios vadybos atejusių ị rezultatus orientuotos veiklos ir elgsenos įtvirtinimą valstybès tarnybos institucinèje funkcinejje praktikoje [17, p. 476-477].

Valstybès tarnybos departamento parengtame valstybès tarnybos reformos krypčių ir iššūkių projekte, kuriam 2013 m. du kartus pritare Lietuvos Respublikos Vyriausybės strateginio planavimo komitetas, esminiu reformos pagrindu laikoma valstybės tarnybos struktūrų ir valstybės tarnautojų kompetencijų ugdymas išskiriant jas ị:

Bendrąsias kompetencijas (viešosios vertès kūrimas, valstybès tarnybos struktūrų organizuotumo lygmuo, institucijų veiklos patikimumas ir atsakingumas, valstybès tarnybos kaip sistemos analitinių pajègumų kokybiniai parametrai bei viešosios komunikacijos plètros lygmuo); 
Vadybinès ir lyderystès kompetencijas (modernus požiūris ị strateginio valdymo galimybių išnaudojimą, veiklos valdymo ir lyderystės ugdymo, kas yra itin reikšminga naujojo viešojo valdymo kontekste).

Be to, reformos projekte yra išskiriamos specifinès ir profesinès kompetencijos atskiroms valstybės tarnautojų pareigybių grupėms [5].

Vertinant suformuluotas užduotis galima sutikti su jų identifikavimo tikslingumu. Juo labiau kad nuo ịstojimo ị ES Lietuvos valstybès tarnybos organizaciniai ir individualūs valstybès tarnautojų gebejjimai dažnai europinių institucijų buvo akcentuojami kaip ne itin stipri grandis valstybès tarnybos veikloje.

Suprantant naująji viešajị valdymą kaip inovatyvų, kūrybingą procesą, siejamą visų pirma su valstybès tarnybos sistemos funkcionalumo ir valstybės tarnautojų, kaip žmogiškųjų išteklių, specifinès rūšies kokybinėmis dimensijomis, galima teigti, kad valstybès tarnybos struktūrų ir valstybės tarnautojų korpuso vaidmuo yra svarbiausia valstybės politinès, ekonominès, socialinès, kultūrinès ideologinès plètros sąlyga. Todèl viena iš svarbiausių Lietuvos valstybès tarnybos reformavimo krypčių yra veiklos vertinimo pokyčių nustatymas.

\section{1 lentele. Numatomi valstybės tarnautojų vertinimo pokyčiai [5]}

Kompetencijų vertinimas nesiejamas

su darbo užmokesčiu

Kompetencijų ugdymas

Kompetencijas vertina pats valstybès tarnautojas ir jo tiesioginis vadovas

Aukštesniujų vadovų kompetenciją vertina jis pats, tiesioginis vadovas, pavaldiniai ir kolegos
Veiklos vertinimas

Skatinimas už veiklos indèlị ir rezultatus

Vertina tiesioginis vadovas Sprendimą priima ì pareigas priimantis asmuo

Valstybès tarnybos struktūroms XXI a. pradžioje tampa būtina tobulinti integruoto valdymo patyrimą, suvokiant integraciją įvairiais aspektais ir formomis, t. y. kaip integruotas ịvairių sektoriu pastangas, decentralizuoto ir centralizuoto valdymo poreikių balansą, išskirti veiklos strateginius prioritetus ir jų igyvendinimo taktines priemones bei kt. Minèti uždaviniai vienaip ar kitaip buvo formuluojami Lietuvos Respublikos Vyriausybès strateginiuose dokumentuose, tačiau galima teigti, kad nemažai planuotų spręstinų uždavinių buvo ir yra tik iš dalies igyvendinti, t. y. neturi sisteminių pokyčių pobūdžio, nes jie buvo sufokusuoti tik ị atskirus fragmentuotus sprendimus. Dalis atsakomybės už tai tenka valstybės tarnybos struktūroms [10].

\section{Pokyčių valdymo dekompozicija valstybès tarnybos struktūrose}

Viešojo valdymo sistemų (kurių viena iš esminių yra valstybės tarnyba) kaitos procesų analizei reikalingos šiuolaikinès tyrimo metodologinès prieigos, nauju 
tyrimo logikos principų įsisavinimas, kadangi tarp valdymo procesų kaitos dedamųjų svarbiausia tampa viešojo valdymo kompleksinio kontekstualumo dimensija, apimanti visuomeninių procesų kaitos visumą. Todèl valstybės institucijoms, valstybės tarnybai, kaip sistemai, ir valstybės tarnautojų grupėms, kaip subsisteminiams dariniams, XXI a. pradžioje tenka radikaliai keisti veiklos formas, metodus, procedūras, ieškoti naujų valdymo modernizavimo metodologijų projektuojant institucijų veiklos permanentinị atsinaujinimą, strateguojant valstybès valdymo institucijų veiklos kryptis atsižvelgiant ị globalius iššūkius, suponuojančius pokyčių valdymą, modernių reformų ir inovatyvių valdymo priemonių paieškas.

Analizuojant XXI a. valdymo pokyčius, galima išskirti epizodinius ir permanentinius pokyčius. Epizodiniai pokyčiai dažnai yra suponuoti organizacijos išorinès aplinkos poveikių, o permanentiniai -dažniau sietini su organizacijų vidinès aplinkos tendencijomis - visu pirma su nuoseklumo, stabilumo, efektyvumo, konfliktų valdymo, vystymosi ciklų, strateginio planavimo dimensijomis. [6, p. 376]. Todèl valstybės tarnybos kokybinis augimas XXI a. pradžioje nesuvokiamas be sisteminių viešojo valdymo reformų, be valstybès tarnybos struktūrų ir valstybės tarnautojų gebejjimų adaptuotis prie naujų ekonominių, politinių aplinkybių ir sąlygų, reikalingų kompetencijų, atsakomybės ir atskaitomybės ugdymo, valstybės tarnybos struktūrų kontrolès, veiklos savianalizès funkcinių pajėgumų atsinaujinimo [8, p. 122-123].

Kaip viena iš svarbiausių pokyčių valdymo dedamųjų valstybės tarnyboje yra išskiriamas viešosios politikos (kaip sudètinès viešojo valdymo dalies) rengimo ir igyvendinimo procesų kontekstas, politikos strategijų, programų, projektų vieta valstybės valdymo struktūroje. Naujojo viešojo valdymo struktūroje viešosios politikos formavimas daugiau siejamas su valstybės valdymo tikslų formavimu ir igyvendinimu, reikalaujančiu subalansuoto vidinių ir išorinių valstybės kaip politinès teritorinès organizacijos faktorių ir sąlygų, administracinio kūrybingumo, kaip valdymo potencialo veiklos tikslingumo ir efektyvaus panaudojimo [14, p. 8-11].

Valstybės tarnybos sistemoms rengiant ir igyvendinant politikos strategijas, valstybines programas reikalingos intelektualinès, organizacinès, materialios ir motyvacinès pastangos, valstybės institucijų elgsenos pokyčiai, galintys sudaryti prielaidas strategiškai orientuotiems viešosios politikos formavimo ir igyvendinimo kokybiniams parametrams realizuoti. Valstybės tarnybos šiuolaikinio etapo pokyčiai leidžia visuomenei, piliečiams tikètis, kad geriau bus realizuojami jų teisèti lūkesčiai dẻl socialinių paslaugų tekimo kokybẻs, socialinės atskirties mažinimo bei kitų socialinių problemų, kurių sprendimus didele dalimi lemia valstybės tarnybos, kaip esminès viešojo valdymo subsistemos, kompleksinès veiklos tobulinimas, jungiantis savyje modernią, viešumą ir skaidrumą užtikrinančių sąlygų, priemonių ir atsakomybės formų visumą [15, p. 818-824].

Valstybès tarnybos departamento $2013 \mathrm{~m}$. ataskaitoje buvo išskirtos ir apibendrintos pagrindinès valstybès tarnybos funkcionalumo problemos. Tai - nepakankamai stipri aukštesniųjų kategorijų ir vadovaujančių valstybès tarnautojų grandis bei žemas valstybès tarnybos patrauklumo lygmuo. Kartu būtina pabrèžti, 
kad Lietuvos valstybės tarnybos pokyčiai XXI a. pradžioje ne kartą buvo pozityviai įvertinti įvairių pasaulinių organizacijų ekspertinių institucijų.

\section{2 lentelè. Valstybės tarnybos pokyčių vertinimas [20]}

\begin{tabular}{|l|l|l|}
\hline Vertintojas & Metai & Vertinimo turinys \\
\hline OECD-SIGMA & 2003 & $\begin{array}{l}\text { Palankus vertinimas: „Lietuvos valstybès tarnybos įstatymas } \\
\text { iš esmès suderintas su ES šalyse } \\
\text { taikomais principais ir standartais“, o „,valstybės tarnybos } \\
\text { valdymo sistema gerai sudaryta“ }\end{array}$ \\
\hline $\begin{array}{l}\text { PASAULIO } \\
\text { BANKAS }\end{array}$ & 2006 & $\begin{array}{l}\text { Politizacija: antrasis aukščiausias lygmuo (,iš esmės pasiektas } \\
\text { standartas“, geriausias tarp Rytų ir } \\
\text { ir Vidurio Europos šalių } \\
\text { Paskatos: trečiasis aukščiausias lygmuo (,dalinai pasiektas } \\
\text { standartas“, antras geriausias po Latvijos }\end{array}$ \\
\hline SIGMA & 2009 & $\begin{array}{l}\text { Geriausia atitiktis Europos viešojo administravimo principams } \\
\text { tarp Rytu ir Vidurio Europos šalių }\end{array}$ \\
\hline
\end{tabular}

Pozityvūs vertinimai dar aktualesniais iššūkiais valstybės tarnybai daro valstybès tarnybos institucinių kompetencijų, inovatyvių pokyčių valdymo technologijų igyvendinimą. Todèl itin svarbios tampa naujojo viešojo valdymo ideologinès teorinès nuostatos, kaip besiformuojančios paradigmos pagrindas formuojant valstybės tarnybos veiklos kryptis, kai svarbiausia problema ir silpniausia grandis siekiant valstybės valdymo (ir valstybės tarnybos) modernizavimo yra metodologijų trūkumas, t. y. veiklos logikos instrumentų visumos instrumentarijaus trūkumas rengiant praktines valstybinès reikšmès politinių tikslų ir uždavinių planavimo kryptis, prognozuojant galimas igyvendinimo funkcijas ir tendencijas. Lietuvos valstybès tarnybos reformos projekte tai plačiai akcentuojama.

\section{Esminės veiklos kryptys ir užduotys valstybės tarnybai XXI a. pradžioje}

Siekiant tobulinti viešojo valdymo kokybę ir didinti valstybės tarnybos efektyvumą, būtina formuoti naujus kokybinius reikalavimus veiklos valdymo, valstybès tarnautojų gebejjimų inovacines formas ir metodus, procedūras, orientuotas ị visuotinès kokybės vadybos, ị rezultatus orientuotos elgsenos ịtvirtinimo, žinių valdymo, socialinès korporatyvinès atsakomybės ir naujų veiklos kontrolès formų plètrą ir ịtvirtinimą praktinèje valstybès struktūrų veikloje [19, p. 128-131].

Igyvendinat minètus iššūkius valstybės tarnyboje, reikalinga visa apimanti stebėsenos ir vertinimo integracija. Tokios, integruotos vertinimo sistemos sukūrimas reikalauja iš valstybės tarnybos vadovų, institucijų lyderių siekti išeliminuoti vertinimo subjektyvumą, remiantis netinkamais vertinimo kriterijais, 
nepakankama ekspertų ir ekspertizių atlikimo kokybe vertinimo procesuose. Visa tai yra struktūriniai valstybės tarnybos efektyvios veiklos komponentai, kurie negali būti traktuojami, taikomi, interpretuojami kaip atskiros, nesusietos sistemos dalys. Valstybès tarnybos efektyvumo struktūroje minèti komponentai gali būti apibendrintai sujungiami ir traktuojami bendriausiuose valdžios struktūrų ir funkcijų, valstybės tarnybos politikos, strateginių programų, koncentruotų veiklos valdymo formų, metodų ir modelių rémuose [1].

Globalizacijos mastai suponuoja naujus reikalavimus visų rūšių organizacinès integracijos procesams. Šiandien naujojo viešojo valdymo plètros etape organizacinių sistemų charakteristikos indentifikuojamos kaip postbiurokratinès struktūros, matricinès organizacijos, o organizacijų tinklaveika naujos viešosios vadybos sąlygomis grịsta viešąja ir privačiąja partneryste sparčiai transformuojasi ị ịvairias visų rūšių sektorių ir lygių organizacinès sąveikos formas, vadinamąją tarpsektorinę integraciją [13, p. 97-115; 21, p. 2-4]. Valstybės tarnybos užduotis tarpsektorinès integracijos terpeje, kur dominuojančiais veiklos ir elgsenos determinantais tampa naujos vadybinès kultūros, strateginès partnerystès principų, valdymo demokratizavimo, inovatyvių pokyčių valdymo metodų paieška ir įtvirtinimas viešojo valdymo praktikoje, yra ugdyti gebejjimus koordinuoti multiorganizacinès veiklos dalyvių pastangas, pasitikèjimą, veiklos kontrolès ir atsakomybės formų vystymą [3, p. 151-171].

Todèl valstybės tarnybai, valstybès institucijų vadovams, organizacijų lyderiams itin svarbiais iššūkiais tampa:

- Suprasti, kaip veikia matricinès, politikos ir vadybos tinklų pagrindu veikiančios kompleksinès struktūros;

- Toliau plètoti interorganizacinị tinklaveikos pobūdị;

- Tarp naujojo viešojo valdymo indikatorių akcentuoti sprendimų rengimą konsensuso, dialogo, kompromisų forma, plètojant organizacijų kultūrą kaip institucines vertybes [9, p. 22-23].

- Valstybès tarnybos struktūroje diegti atvirumo ir skaidrumo bei socialinio atsakingumo principus.

Modernizuojant valstybės tarnybos organizacijų veiklą daugiau remtis pasitikejjimo, demokratinių principų igyvendinimo, horizontalios ir vertikalios informacijos sklaidos, t. y. ịvairias valdymo formas ir grandis jungiančiais sprendimais, būdingais naujojo viešojo valdymo etapui, kuriame naujojo tipo organizacijos dažnai ivardijamos kaip modernios, ,geros“ organizacijos [7, p. 192].

Tokių valstybės institucijoms iškilusių iššūkių realizavimas priklauso nuo daugelio faktorių ir sąlygų, kuriuos galima tipologizuoti:

- Koks yra tarporganizacinès integracijos plètotės mokslinių diskusijų, tyrimų ir rezultatų argumentacijos lygmuo.

- Kaip valstybės tarnyba, kaip valdymo sistemos dalis, ir jos institucijos geba gerinti ir adaptuoti geriausią pasaulinę valdymo modernizavimo praktiką diegiant inovacines valdymo formas ir priemones. 
- Kiek valstybės tarnyba geba sutelkti esamą valdymo potencialą, išteklius, ekspertų sistemas, valstybės reformų ir modernizavimo patirti sprendžiant visuomenei aktualias socialines ekonomines problemas, t. y. kaip pavyksta įtraukti kuo daugiau suinteresuotųų kooperuojant teorines ir praktines veiklos galimybes kuriant viešąją vertę.

- Kaip valstybès tarnybos institucijos vadovai, lyderiai yra pasirengę bendram tarpsektorinio planavimo igyvendinimo veiksmų derinimui, akcentuojant politinių programinių strateginių tikslų agregavimo principų išskyrimą, atsakomybès pasidalijimą ir rizikos faktorių bei trukdžių, modernizuojant valstybès tarnybą, indentifikavimą laiku ir pastangas laiku juos eliminuoti [12, p. 127-128; 353-365].

Ekspertų duomenimis, šiuolaikinès Lietuvos valstybės tarnyba, kaip viešojo valdymo sistemos pagrindas, turi nemažai problemų ir trūkumų:

- Trūksta vienodų reikalavimų sistemos, vertinant valstybės tarnautojų žinias ir gebejjimus.

- Esama darbo užmokesčio sistema neatitinka valstybės tarnybos veiklos vertinimo objektyvumo reikalavimų.

- Nepakanka lankstumo karjeros, darbo užmokesčio, motyvavimo, mokymo ir lavinimo srityse.

- Vadovų lyderystės stoka neužtikrina pakankamos valstybės tarnybos ir interesų grupių sąveikos ir bendradarbiavimo.

Todèl Lietuvos valstybės tarnybos departamentas kaip svarbiausius veiklos modernizavimo uždavinius išskiria:

- Modernių atrankos i valstybès tarnybą procesų igyvendinimą;

- Kompetencijų modeliavimą ir valstybès tarnybos kompetencijų modelio parengimą;

- Vadovavimą ir vadovų - lyderių korpuso stiprinimą;

- Darbo užmokesčio sistemos tobulinimą;

- Valstybès tarnautojų mokymo - lavinimo sistemos reformavimą [20].

Taip tipologizuojant valstybès tarnybos modernizavimo veiklos kryptis ir užduotis, sąlygas ir faktorius, būtina ịvaldyti modernias veiklos vertinimo formas, metodus ir procedūras, naudoti tinkamus indikatorius ir rodiklius, kurių teorine metodologine baze išlieka ị veiklos rezultatus orientuotos organizacijų veiklos ir organizacinès elgsenos principinès nuostatos. Galima teigti, kad modernizuojant valstybès tarnybos veiklą būtina ịvaldyti išsamią modernizavimo tendencijų ir krypčių analizę bei ekstrapoliacinio vertinimo procedūras, organizacijų pokyčių teorinį modeliavimą ir praktinị organizacijų veiklos planavimą, veiklos priežiūrą, modernių kontrolès, audito, savianalizès, kaip veiklos vertinimo formų, plètrą, atsižvelgiant ị vertinimo struktūrų pasirinkimą, jų kompetencijos lygmenị vertinant valstybės tarnybos paslaugas visuomenei, kaip esminius valstybès tarnybos teikiamų paslaugų kokybinių veiklos parametrų vertinimo principus [22, p. 150-161]. 
XXI a. viešojo valdymo reformos orientuoja valstybès tarnybos institucijas, valstybės tarnybą, kaip sistemą, ir jos posistemes ị naująą valstybės ir nevyriausybinio sektorių sąveikos lygmenį daugelyje visuomenès veiklos sferų. Vadinamasis trečiasis sektorius tampa realiu ir veiksmingu viešųjų produktų ir paslaugų bendrakūreju tarpsektorinès integracijos terpeje, formuojasi inovacinè aplinka ir inovatyvios viešojo dalyvavimo formos [19, p. 250]. Ištobulintos pozityvios viešosios ir privačios partnerystės formos naujosios viešosios vadybos praktikoje šiandien sparčiai papildomos valstybės institucijų ir nevyriausybinio sektoriaus organizacijų sąveikos formomis, kurių esminis skirtumas nuo XX a. pabaigos šių sektorių bendradarbiavimo yra žymiai glaudesnè integracija vadybinès veiklos, programų ir projektų valdyme, kuriant viešąą vertę, kada trečiojo sektoriaus institucijų pacifistinè, indiferentiška pozicija igauna vadybinès kooperacijos, kaip kūrybingo strateginio valdymo, charakteristikas ir bruožus [16, p. 223-224].

Tai nėra lengvai igyvendinama. Neretai siekiai plètoti tarpsektorinès integracijos procesus susiduria su visų trijų sektorių kontrapreneriška veikla, stabdančia integracinès sąveikos kokybinius pokyčius, inovacines sąveikos kryptis ir tendencijas. Toks, kartais aktyvus pasipriešinimas lemia naujosios viešosios vadybos disfunkcijų, suponavusių hipertrofuotą valstybės vaidmens sumažejimą, viešojo sektoriaus marketizavimo, privataus sektoriaus valdymo modelių ịsigalèjimą. Dažnai tarp integracijos partnerių netolygiai paskirstomi ịsipareigojimai, atsakomybė už veiklos riziką, pasireiškia netgi piktnaudžiavimo praktika, siekiant išvengti nepelningos rizikos dalies, atsakomybès ir kt. [4, p. 475-484].

Siekiant sistemiškai pateikti detalizuotas užduotis šiuolaikinei valstybės tarnybai naujojo viešojo valdymo kontekste, reikia išskirti nemažai faktorių grupių ir prioritetų, tiesiogiai turinčiu įtakos valstybès tarnybos efektyvumui. Vienas iš svarbiausių yra siekis ir galimybės užtikrinti valstybès tarnybos struktūrų sprendimų rengimų analitinị potencialą, kurio tikslas laiku ir tiksliai, remiantis šiuolaikinėmis viešojo valdymo teorijomis, modeliais suprasti valstybės tarnybos veiklos procesų sudètingumą, jų dekompoziciją, galimas alternatyvas. Tam reikalingos komunikacijos viešojo valdymo ir kitų sektorių integracinėje erdvejje, gebejjimai strategiškai mąstyti, planuoti, geriau panaudoti integruoto žinių valdymo formas ir galimybes igyvendinant veiklos strateginius prioritetus [11, p. 214-215]. Kaip tokius prioritetus moderni valstybès tarnyba išskiria - demokratinio valdymo metodus, visuomenės interesų grupių derinimą, viešosios etikos standartus, skaidrumo ir korupcijos prevencijos principus, valstybès tarnautojų lavinimą, siekiant jų kompetencijų potencialo didinimo. Atskirais klausimais kaip valstybès tarnybos užduotis reiktų išskirti valstybės tarnybos struktūrų kokybinius pokyčius, permanentinị atsinaujinimą, viešujų ryšių tobulinimą ir informacinių sistemų veiklą bei kitus viešojo valdymo proceso turinio kokybės parametrus [18, p. 92-98]. Tik moderni valstybės tarnyba šiandien gali adekvačiai reaguoti ir adaptuotis prie globalios aplinkos suponuotų uždavinių, užtikrinti geriausios pasaulinès patirties sklaidą diegiant moderniausias valstybės tarnybos veiklos patirtis lokalioje erdveje. 


\section{Išvados}

1. XXI a. valstybès tarnybos kaitos dimensijų atskleidimas reikalauja gebėjimų suprasti modernaus viešojo valdymo kompleksiškumą, multiorganizacinès veiklos charakteristikas, kaip globalią terpę valstybès tarnybos sistemų ir subsistemų veiklos modernizavimui, siejamam su valstybės tarnybos reformavimu, inovacinių veiklos metodų įtvirtinimu valstybės tarnybos institucijų veiklos procesuose. Valstybès tarnybos modernizavimas neatsiejamas nuo viešojo valdymo demokratinio konteksto, t. y. aktyvaus piliečių, jų institucinių darinių, interesų grupių dalyvavimo rengiant ir iggyvendinant valstybès strateginio vystymo programas ir projektus.

2. Sèkminga valstybès tarnybos, kaip sistemos, veikla priklauso nuo vidinių ir išorinių sąlygų, tarp kurių esminis vaidmuo priklauso valstybės tarnautojų korpuso kompetencijų ir gebėjimų kokybinėms charakteristikoms. Moderni valstybės tarnyba - tai struktūrų visuma, gebanti radikaliai keisti veiklos formas, sutelkti pastangas racionaliai valdant visų rūšių išteklius. Tokie uždaviniai neatsiejami nuo ịvairių lygių valstybès tarnybos struktūrų vadovų atsakomybės augimo, viešosios etikos ir nepriekaištingos reputacijos, valstybès tarnautojų administracinio kūrybingumo, vadovavimo ir vadovų lyderystès užtikrinimo.

3. Formuluojant tolesnes valstybès tarnybos modernizavimo kryptis ir užduotis būtina siekti sukurti integruotas monitoringo ir veiklos vertinimo sistemas, išskirti aiškius vertinimo kriterijus, kuriais remiantis būtų galima žymiai objektyviau ir tiksliau identifikuoti valstybės tarnybos institucijų ir valstybės tarnautojų potencialias galimybes, tobulinti valstybės tarnautojų registrą, kaip instrumentą, veikianti karjeros pokyčius, motyvacijų tobulinimą, mokymo ir lavinimo procesų organizavimą. Valstybės tarnyba šiandien turi sutelkti analitines ekspertines pajègas, taip sukuriant palankias sąlygas veikti valstybės tarnybos institucijoms tarpsektorinės integracijos erdvėje, visų rūšių tinklaveikos organizacinėse struktūrose ir kitose inovacinèse valdymo formose.

\section{Literatūra}

1. Bovaird, T., Loffler, E. Public Management and Governance. London: Routledge. 2009.

2. Denhardt, J., Denhardt, R. The New Public Service: Serving not Steering. New York: M.E.Sharpe. 2003.

3. Dobbs, L., Moore, Ch. Enganging Communities in Area - based Regeneration: The Role of Participatory Evolution. Policy Studies. Vol. 23, No. 3-4, 151-171.

4. Forrer, J., Kee, J., Newcomer, K., Boyer, E. Public - Private Partnerships and the Public Accountability Question. Public Administration Review, 2010. Vol. 70, No 3, 475-484.

5. Galimos valstybės tarnybos reformos kryptys ir iššǔkiai. Vilnius: Valstybės tarnybos departamentas, 2012.

6. Handbook of Organizational Change and Innovation Challenge. Eds. M. Poole, Van de Ven. Oxford: University Press, 2004. 
7. Hill, K., Lynn, L. Public Management: A Three Dimensional Approach. Washington: D.C. CQ Press. 2009.

8. Laegreid, P., Verhoest, K. Governance of Public Sector Modernization. London: Palgrave McMillan. 2010.

9. Lane, J-E. State Management. London: Routledge. 2009.

10. Lietuvos Respublikos Vyriausybės 2004 m. balandžio 28 d. nutarimas Nr. 488 (.04.) „Dèl viešojo administravimo plètros iki 2010 m. patvirtinimo“. Vilnius, 2004.

11. McNabb, D. The New Face of Government. New York: CRC Press. 2009.

12. Mc Quaid, R. Theory of Organization Partnership: Partnership, Advantages, Disadvantages and Success Factor. In. St. Osborne (ed.). The New Public Governance. London: Routledge. 2010.

13. Melian-Gonsalez, A., Batista-Carino, R., Sančes-Medina. Identifying and Assesing Valuable Resources and Core Capabilities in Public Organizations. International Review of Administrative Sciences. 2010. Vol.78, No. 1, 97-115.

14. Ortega, K., Eizaquirre, A., Cuenca, M. Can Leisure Studies Enlighten the Development of Cultural Audencies? Journal of Culture Management and Policy. 2012, Vol 2, No 2, 8-11.

15. Ostrom, V. Doing Institutional Analysis Digging Deeper than Markets and Hierarhies. In C. Menar., M. Shirley (eds.) ( Handbook of New Institutional Economics. New York: Sharpe.

16. Pestoff, V., Brandsen, I. Public Governance and the Third Sector: Opportunities for Coproduction and Innovation. In. St. Osborne (ed.). The New Public Governance. London: Routledge. 2010.

17. Pivoras S. Konkursinès atrankos ị Lietuvos valstybės tarnybą tobulinimas gero valdymo iššūkių perspektyvoje. Viešoji politika ir administravimas. 2012, Nr. 11(3), 476.

18. Potuček, M. The Capacities to Govern in Central and Eastern Europe. Bratislava. NISPAcee. 2004.

19. Raipa, A. ir kiti. Modernus viešasis valdymas. Kaunas: Vitae Litera, 2012.

20. Valstybès tarnyba: Problemos ir tobulinimo perspektyvos. Vilnius, 2013.

21. Wall, A. Public - Private Partnerships in the USA. New York: Tailor and Francis. 2013.

22. Warner, M., Hefets, A. Managing Markets for Public Service: The Role of Mixed Public/ Private Delivery of City Service. Public Administration Review. 2008. Vol. No. 68(1), 150-161.

\section{Alvydas Raipa}

\section{The Challenges to Public Service in the Context of the New Public Governance}

Abstract

The authors in the article, on the basis of a meta-analysis, theoretical modeling, interpretive method and the method of comparative analysis, seek to describe civil service, as a component of public governance system, and changes of its functional activities. In the beginning of the twenty-first century, the dominant base doctrine became the new public governance, as the product of the evolutionary process of the new public management. Today, its indicators and activities' specifics are extensively discussed.

In the content of the article, the authors purposefully seek to accomplish the following tasks: to distinguish the characteristics of the changes in a civil service system and all levels subsystems, decomposition elements of public service structural-functional changes, 
mechanisms and typology of changes and their management; to emphasize public interest groups and fulfillment of their expectations, as the most important institutional-functional performance targets of civil service.

The authors understand and use the functionality of civil service as a characteristic of certain conditions and factors, which connect innovative and creative activities, highlight strategic priorities, balance centralized and decentralized management and improve the implementation of decisions.

Discussing the operational efficiency of civil service in the beginning of the twenty-first century, the authors emphasize the increased qualitative requirements of today's civil service system, the tasks for civil servants, which seek to establish new and results-oriented forms of behavior, dissemination of innovative activities and development of inter- organizational networking.

Alvydas Raipa - Mykolo Romerio universiteto Politkos ir vadybos fakulteto Viešojo administravimo instituto profesorius.

E. paštas: alvydasraipa@mruni.eu

Alvydas Raipa, Doctor of Social Sciences, Mykolas Romeris University, Faculty of Politics and Management, Department of Public Administration, Professor.

E-mail: alvydasraipa@mruni.eu

İteiktas 2014 m. rugsèjo 10 d.; recenzuotas; parengtas spausdinti lapkričio mèn. 